\title{
ESCRITA VS FALA: QUESTIONANDO A VISÃO REPRESENTACIONISTA ${ }^{1}$
}

\author{
WRITING VS SPEECH: A CRITIQUE OF THE REPRESENTATIONALIST VIEWPOINT
}

\author{
Cristiano Mahaut de Barros Barreto \\ Universidade Federal Fluminense \\ cristianombb@gmail.com
}

\section{RESUMO:}

Este artigo objetiva explorar a possibilidade de uma relação entre a escrita e a fala enquanto dois sistemas interdependentes. Partimos da hipótese de que a visão representacionista, que considera a escrita subordinada à fala, é prevalente nos estudos formais sobre a linguagem, sustentando-se, entretanto, sobre pressupostos frágeis e movediços. Afiliado à abordagem wittgensteiniana, o artigo recusa-se a oferecer uma alternativa teórica acabada, optando por movimentos fragmentários e oferecendo "colagens" e impressões sobre o tema da escrita. Desta forma, sugerimos três abordagens alternativas que, a despeito de suas amplas diferenças, colocam em cheque a tese da heteronomia da escrita.

PALAVRAS-CHAVE: Escrita, História das Ideias Linguísticas, chinês, Foneticismo, Sylvain Auroux, Roy Harris

\section{ABSTRACT:}

This article explores the possibility of a relationship between writing and speech as two interdependent systems. Our hypothesis is that the representational viewpoint, which considers writing as subordinated to speech, is prevalent in formalist studies on the language and that it is however grounded on fragile and unstable postulations. Assuming a Wittgensteinian approach, the article declines to offer any definitive theoretical solution, adopting fragmentary movements and offering "collages" and impressions on the subject of writing. Thus, we suggest three alternative approaches that, despite their wide disparities, cast serious doubts on the thesis of writing heteronomy.

KEY-WORDS: Writing, History of the Language Ideas, Chinese, Foneticism, Sylvain Auroux, Roy Harris

\footnotetext{
1 Artigo vinculado a projeto de pós-doutoramento com apoio do CNPq, Processo n. ${ }^{\circ}$ 152017/2016-0.
} 


\section{Introdução}

Uma das mais influentes e citadas passagens onde podemos ver resumida a visão tradicional ocidental sobre linguagem e sentido nos remete ao tratado Da Interpretatione de Aristóteles:

Os itens na elocução são símbolos das afecções na alma, e os itens escritos são símbolos dos itens na elocução. E assim como os caracteres escritos não são os mesmo para todos, tampouco as elocuções são as mesmas. Entretanto os itens primeiros dos quais estas elocuções são sinais - as afecções da alma - são os mesmos para todos, assim como são as mesmas as coisas, das quais estas afecções são semelhanças. (DE INTERPRETATIONE, 16a3, trad. Lucas Angioni)

Sem nos deter sobre as muitas possibilidades desta críptica passagem, sua imensa influência se faz sentir através da frequente leitura que nos remete à proposta de uma cadeia especular e unidirecional de linguagem, onde o Mundo se mostra igual para todos (as "coisas"), e deixa a mesma impressão em cada pessoa (as "afecções"). Neste cenário, cada cultura irá usar sua própria língua, complexos acústicos particulares (as "elocuções") que simbolizem essas afecções e, posteriormente, fará o mesmo na criação de uma escrita (os "caracteres escritos"), que por sua vez simbolize as referidas elocuções.

A escrita, conquanto reconhecida como uma das mais importantes inovações da humanidade e absolutamente central nos estudos culturais, antropológicos e históricos, é reconhecida neste trecho fundador do pensamento ocidental como o último elo da cadeia aristotélica de representação. A linguística contemporânea, que se estabelece progressivamente enquanto disciplina acadêmica e estudo científico nos inícios do século $\mathrm{XX}^{2}$, procurou, particularmente nas suas vertentes formalistas, se desvencilhar da importância histórica dada à escrita, elegendo-se como o estudo da fala, e assim delegando à primeira certo status precário, modo de representação suporte à segunda e, portanto, incapaz se ser tomada enquanto sistema linguístico minimamente independente.

A nova ciência da linguística buscou delimitar um objeto central e isolado de pesquisa e se desvencilhar de uma herança filológica vetusta que se debruçava sobre a palavra escrita e ignorava o fato de que as sociedades ágrafas representam a evidência necessária inconteste para equacionar linguagem e

Sobre a história da linguística na virada do século XIX para XX e seu movimento de consolidação como ciência autônoma e disciplina acadêmica, veja-se, por exemplo, Auroux (2000), Joseph \& Love (2001) e Mopurgo-Davies (2014). 
fala. A relativa novidade da escrita em relação à linguagem (falada) implicaria na impotência da primeira como fator modificador da segunda. Destarte a escrita, um vez liberta das especulações renascentistas na qual seria um presente de Deus (Hudson, 1994), passou a ser universalmente reconhecida como uma invenção humana - ferramenta a ser conscientemente adquirida - portanto com poder limitado para afetar o que é uma capacidade humana, parte da própria natureza do Homem: a linguagem. A tese da heteronomia da escrita implicou na ausência de uma "ciência da escrita" autônoma e consolidada, em uma recepção acadêmica extremamente restrita e na quase inexistência de publicações no país. ${ }^{3}$

O presente artigo propõe-se a ajudar a suprir, ainda de que de uma forma incipiente, esta lacuna, colocando em questão a posição coadjuvante da escrita nos estudos da linguagem. Ele objetiva a identificação do viés representacionalista que está presente nas abordagens formalistas da linguística e de seu impacto em relação à questão do status da escrita dentro das ciências da linguagem, dos problemas que tal visão acarreta, e de algumas estratégias utilizadas para lidar com estas questões. Como se trata de uma problemática muito complexa que se estende por diversas área da produção acadêmica (estudos da linguagem, literatura, filosofia, estudos culturais, entre outros ${ }^{4}$ ), neste artigo optou-se pelo foco sobre três livros seminais de pensadores que, de uma forma muito diversa, abordaram a questão da escrita e identificaram as bases precárias de certas premissas constitutivas dos modelos formais onde a escrita aparece como mero epifenômeno. Sua seleção não pretende oferecer um quadro inclusivo ou mesmo representativo de estudos sobre a escrita que questionem o paradigma representacionalista, e sim opta por fazer uma espécie de "colagem" (collage), oferecendo uma abordagem não reducionista no que Ludwig Wittgenstein chamou de uma "apresentação panorâmica" 5 e fragmentária sobre a escrita. Seguindo os passos do famoso filósofo vienense, advoga-se uma abordagem que procure nos dar a ver conexões, "elos intermediários," invisíveis às teorias formais totalizantes, e assim instigar novas perguntas ao invés de nos limitar

Pauluk (2004) e Autor (2011) são excessões ao apresentarem discussões sobre os sistema de escrita, além do tema majoritariamente abordado sobre a aquisição e ensino de escrita. Outras obras escritas por autores estrangeiros e editadas no país são: Catach, 1996; Sampson [1985]1996, Higounet [1955]2004; e Fischer (2009).

4 Veja-se, por exemplo, McLuhan (1964), Havelock (1986), Ong (1992) e Rubin (1997). Para uma revisão crítica sucinta dos estudos da escrita que tomaram uma abordagem culturalista/ social e a análise comparativa das culturas orais e letradas, veja-se Galvão \& Batista (2006).

5 Sobre a noção de "aprentação panorâmica" (übersichtliche Darstellung) veja-se Wittgenstein (2009, §122), analisado em detalhes em Baker \& Hacker (2009, capítulo XV). 
à procura de respostas para as mesmas avelhantadas perguntas. Neste aspecto, os três autores aqui selecionados nos levam, cada um a sua maneira, à pergunta sobre a possibilidade de uma escrita mais rica e poderosa do que tradicionalmente vemos nos estudos da linguagem.

\section{Visões representacionistas}

O status da escrita dentro das ciências da linguagem sofreu enormes mudanças ao longo do tempo e até hoje não ele não congrega uma posição consensual no ocidente. ${ }^{6}$ Seu estudo está profundamente entrelaçado a questões teóricas importantes sobre a linguagem. Até mesmo sobre a circunscrição do significante "escrita" é difícil encontrar uma concordância. Uma visão abrangente tentaria definir escrita como "qualquer atualização física (gráfica) de um sistema semiótico." No presente artigo, quando examinarmos a escrita do seu ponto de vista sistêmico ("sistemas de escrita"), estaremos usando o termo escrita exclusivamente para denominar sistemas de transposição para um meio físico bidimensional de uma língua natural usada ou ainda em uso pela humanidade, a historicamente mais relevante forma de transposição de um meio áudio-oral em benefício de outro meio (no caso, o meio gráfico bidimensional), libertando a comunicação humana da presença obrigatória do emissor da palavra ao passo que consegue manter a identidade da linguagem. ${ }^{7}$

A "definição" de escrita enquanto apoio para uma língua natural falada já nos dá sinais de como é complexa e difícil uma demarcação dos sentidos da escrita que não faça qualquer referência à língua falada. Veremos nesta seção a recorrência frequente deste viés: é o caso, por exemplo, da definição de um dos mais influentes livros dos estudos da escrita do século XX: "Literal e rigorosamente definida, a escrita é a contrapartida gráfica do discurso, a 'fixação' da linguagem falada numa forma permanente ou semipermanente (...)" (Diringer, [1962]1985, p.15).

De uma forma bem geral, ainda nos detendo ao contexto representacionista, nos parece aceitável e em grande parte consensual a afirmação mais ponderada - no sentido em que atribui à escrita algum grau de independência em relação à fala - de que "todos os sistemas de escrita têm interpretações fonéticas e

6 Hudson (1994) nos mostra um panorama detalhado da história dos pensamentos sobre a escrita na Europa entre os séculos XVII e XIX. Auroux (1995, 1995b e 2000), Lepschy (1994, 1994b) e Mopurgo-Davies (2014) oferecem um história das ideias linguísticas mais abrangente que todavia discute em detalhes as "teorias" da escrita aventadas ao longo da história do ocidente.

7 Para uma discussão detalhada sobre as "definições" da escrita, veja-se Auroux (2004, capítulo 2). 
semânticas, [e que] tais sistemas diferem [apenas] na importância relativa que dão a uma ou outra forma de escrita" (Coulmas, 2003, p.33). Essa descrição todavia reflete uma visão em que tomamos a linguagem como um sistema que mapeie diretamente signo e significado e subordinada a uma realidade externa anterior a ela. O signo escrito está duplamente mapeado à expressão fônica e ao significado exposto. Todavia, esta definição mais ponderada acaba por mascarar uma clara predileção dos teóricos da linguagem pela "interpretação fonética" da escrita em detrimento daquela semântica, que habitualmente é considerada inviável e problemática.

Tal estado das coisas parece refletir-se perfeitamente no seminal Cours de Linguistique Général de Saussure: a palavra falada "por si só constitui tal objeto [linguístico]" (Saussure, [1916]2006, p.34) e a escrita, situada fora do sistema interno da linguagem, serve apenas como uma das vias pelas quais o linguista tem acesso ao seu objeto de estudo. ${ }^{8}$ Tão íntima é a relação entre fala e escrita, diz Saussure, que muitos linguistas chegaram a confundir os dois sistemas e acreditar "que a língua fosse inseparável de seu alfabeto" (Saussure, [1916]2006, p.35). ${ }^{9}$ O autor do Cours, ao mesmo tempo em que reconhece a necessidade do estudo da escrita, faz um esforço para retirá-la do que considera um patamar indevido de importância, que Saussure explica ser especialmente causado porque a

imagem gráfica das palavras nos impressiona como um objeto permanente e sólido, mais adequado do que o som para constituir a unidade da língua (...) [A] $\mathrm{s}$ impressões visuais são mais nítidas e mais duradouras do que as impressões acústicas [e, além disso,] a língua literária aumenta ainda mais a importância imerecida da escrita. (Saussure, [1916]2006, p.35) ${ }^{10}$

8 Saussure ([1916]2006, capítulo VI da introdução) chama a atenção para o desacordo sincrônico entre a escrita e a fala, com deploráveis consequências para a escrita, que está fadada a tornar-se um instrumento imperfeito de representação da fala. Todavia as teses de Saussure no Cours sobre a escrita geraram interpretações muito além de uma simples visão reducionista da escrita, como vemos na analíse da crítica do fonocentrismo de Derrida (Da Gramatologia, 1967) e Foucault (As Coisas e as Palavras, 1966) feita por Jean-Louis Chiss e Christian Puech (In: Catach, 1996, capítulo 3). Ao apresentar a passagem do Cours acima, intencionamos aqui destacar a influência da leitura simplista desta "definição" da escrita e do seu papel secundário no objeto de estudo do linguista. Veremos mais adiante como a semiologia saussuriana implícita para a escrita é o ponto de parte na releitura de Roy Harris.

9 Há um longo histórico de ambiguidade entre fala e escrita ao longo da história das ideias linguísticas. Veja-se também as referências sobre esse tema na nota 5.

10 Vemos passagens com um partido teórico semelhante em diversos autores importantes na línguística ocidental após Saussure, tais como: Martinet (1960, p.5); Sapir ([1921]1963, 
Alguns dos pioneiros estudos específicos sobre a escrita no início da segunda metade do século XX também consideraram a heteronomia da escrita em relação à fala. Gelb, considerado por muitos o fundador dos estudos da escrita no século XX, ${ }^{11}$ no seu famoso livro A Study of Writing de 1952 consolidou a hipótese (hoje já largamente abandonada) do desenvolvimento natural de todos os sistemas de escrita a partir de uma escrita cuja conexão com a fala era muito "frouxa," (e assim mais pictográfica) na direção da escrita fonográfica, cuja função principal é a expressão da fala:

Posteriormente a aplicação sistemática da chamada "fonetização" permitiu ao homem expressar suas ideias em uma forma que corresponderia às exatas categorias da fala. A partir deste momento a escrita gradualmente perdeu sua característica de meio independente de expressão de ideias e tornou-se um instrumento da fala. (Gelb, [1952]1969, p.12)

Para Gelb o estágio ideal da escrita - que nenhum sistema teria conseguido atingir - é aquele de "equivalência ponto a ponto, em que uma unidade da fala é expressa por um signo [da escrita], e um signo [da escrita] expressa somente uma unidade da fala" (Gelb, 1952, p.15). Tal estágio não teria sido atingido nem mesmo pelo alfabeto, considerada pelo autor como "a mais desenvolvida forma de escrita." 12

\section{Características da escrita sob a lente representacionista}

A escrita tomada como uma ferramenta representacionista apresenta duas alternativas em seu objeto representado. Uma deles, aquela que tem mais defensores nos estudos da escrita, proclama que o designatum é necessariamente a fala. Esta via impossibilita por definição qualquer escrita dissociada de uma fala, de uma língua (falada) específica. É o partido teórico que aqui convencionou-se chamar de Foneticismo, cujos representantes mais notórios no campo da linguística foram apresentados na seção anterior.

p.19-20); Bloomfield (1933[1955] in Householder, 1971, p.248, 282) e Hall (1950 e 1964 in Householder, 1971, p.249).

11 Veja-se, por exemplo, Daniels (1990) e Pauluk (2003).

12 A ideia do alfabeto como mais desenvolvido sistema de escrita é muito antiga e seu desenvolvimento é abordado em detalhes por Hudson (1994). Outros estudiosos alinhado ao foneticismo de Gelb - embora não necessariamente ao seu evolucionismo - são, por exemplo, Diringer ([1962]1985), DeFrancis (1996), Rogers (2005) e Fischer (2009). 
Ainda subscrevendo o paradigma do representacionalismo linguístico, é possível subverter a cadeia aristotélica se pensarmos na possibilidade da escrita como representação direta das ideias, abdicando do intermédio obrigatório da fala. Os defensores dessa posição, batizamos neste artigo como partidários do Semanticismo, abordagem que será um pouco explorada na próxima seção.

Um dos efeitos da visão foneticista é a hierarquização dos sistemas de escrita -como vimos acima. Sob este ponto de vista, embora seja possível em princípio conceber que a escrita abdique da fala, qualquer sistema desta natureza estaria manchado pelo emblema derrogatório de ser reconhecido como uma "protoescrita", profundamente limitada em suas capacidades representacionistas e expressivas. Assim, "devemos estabelecer uma distinção clara entre escrita 'embrionária' e escrita 'propriamente dita', se quisermos tornar praticável o assunto que nos propomos debater" (Diringer, [1962]1985, p.17).

A via foneticista postula que há um passo fundamental para tornar estes sistemas rudimentares uma escrita "plenamente funcional." Tal passo é dado através do desenvolvimento de "uma relação sistemática entre o inventário de símbolos (significantes) e as unidades linguísticas [...]" (Coulmas, 1996, p.377, minha ênfase). Somente desta forma, argumenta-se, seria possível o uso prático de símbolos que pudessem corresponder a algo próximo da capacidade expressiva de suas línguas faladas.

O caminho para se atingir essa capacidade e distinção seria dado pelo jogo dual entre o som representado através dos grafemas e o significado no âmbito da escrita. As maneiras atestadas que viabilizaram o aumento sistemático do vocabulário de signos escritos foram: 1) utilização do mesmo significante gráfico mantendo-se seu valor fonético como parte (ou totalidade) de outro signo (princípio de rébus) ou 2) utilização do mesmo significante gráfico através de um processo metafórico para a criação de um novo signo. ${ }^{13} \mathrm{O}$ uso do rébus, segundo os teóricos que abraçam a visão foneticista, seria aquele que

marcou o nascimento da verdadeira escrita [...] através da qual o símbolo pictográfico foi usado não motivado pelo seu significado original, mas especificamente para representar o som evocado pelo nome do símbolo. (DeFrancis, 1989, p.50)

13 Como escreve Coulmas (2003, p.46): “[...] os signos mais antigos todos tinham referências concretas, ao passo que significados não referenciais ou abstratos foram adicionados através de extensão metafórica." 
Portanto estaria outorgado a um princípio fonético o processo que capacitou a escrita para que ela atingisse seu estágio plenamente funcional.

Aceitar que todos os sistemas de escrita necessariamente carreguem algum lado fonético está longe de implicar na visão simplista da escrita como uma "fala decaída" (ou, um termo em inglês usado habitualmente, escrita enquanto visible speech). Todavia a visão foneticista enfraquece sobremaneira aqueles que apoiam a tese da autonomia da escrita, não apenas funcionalmente, mas como forma de práxis, onde se habilita o não comparecimento da fala.

Entretanto, mesmo uma abordagem foneticista irá conceder que há diferenças estruturais fundamentais entre a escrita e a fala ${ }^{14}$ que levantam uma série de problemas para a articulação da representação na interface entre estes dois sistemas comunicacionais tão diversos. A seguir ressaltaremos alguns destes problemas que se articulam ao longo dos eixos de comparação entre escrita e fala.

O contraste contínuo/discreto - respectivamente para fala e escrita - é uma das fontes da complexidade da relação entre o dois sistemas, até mesmo porque a própria natureza contínua da fala é também um tema polêmico, como nos mostram as questões sobre a artificialidade das abstrações representadas pelos fones e fonemas, segmentáveis por definição nos estudos da fonética e da fonologia. ${ }^{15}$ Mesmo que assumamos que a fala também possui alguma espécie de intervalos discretos - ainda que menos perceptíveis do que na escrita - a relação entre os dois sistemas linguísticos só pode ocorrer através de algum tipo de arbitrariedade de mapeamento. Para aqueles que tomam uma visão instrumental e representativa da escrita, o mapeamento se dá sempre na direção da fala para a escrita.

Um segundo contraste está diretamente relacionado ao primeiro e ressalta a natureza estática e autônoma da escrita em contraste com uma fala dinâmica e contextual. Essas características nos possibilitariam o exame da escrita (o exame do que foi escrito) em sua dimensão linear de organização de unidades que se juntam para formar unidades maiores e assim por diante. Tal análise se satisfaz na observação e estudo do nível gráfico da escrita por si só. Quais são tais unidades? Como elas se organizam e em que tipo de sequências? Como aceitar ou recusar uma ou outra sequência? Este tipo de depuração envolve a observação da

14 Para uma breve discussão destas diferenças estruturais, veja Coulmas (2003, p.11) ou Autor (2011).

15 Veja uma discussão sobre a articulação entre as segmentações fonéticas e fonológicas em Taylor (1997, p.4-5, 23-4). 
interface entre léxico, morfologia e sintaxe, inclui estudos discursivos e textuais e gera o estudo de abstrações como a palavra, a sílaba, a mínima unidade gráfica (que na escrita alfabética chamamos de letra), entre outras.

Os diversos sistemas de escrita irão lidar de forma diferente com essas unidades da escrita, com a maneira como essas unidades são representadas nos significantes escritos, e como se relacionam com o fluxo dinâmico da fala. De qualquer maneira, a vertente foneticista irá sempre defender que a escrita estática de alguma maneira irá representar a fala dinâmica. Embora as teorias sobre a escrita partam deste pressuposto, elencando as formas de representação no espectro das diferenças tipológicas da escrita, muitas vezes esquecemos que partimos de pressupostos e abstrações que, elas mesmas, são historiáveis. $\mathrm{O}$ castelo da representação evidencia aqui suas bases temporais e movediças, situadas sócio-historicamente. ${ }^{16}$

Em terceiro lugar, consideramos que a escrita mapeie dimensões linguísticas em uma representação gráfica. Desta maneira, ainda que não sejam discutidas questões de autonomia da escrita, os autores foneticistas são obrigados a lidar com a forma como se dá o mapeamento das diversas dimensões da linguística (fonética, fonologia, morfologia, sintaxe, semântica, análise textual, etc.) em sua dimensão gráfica. Esse mapeamento segue regras mais ou menos explícitas, possui certa regularidade, mas frequentemente aparece repleto de exceções aparentemente não ou pouco motivadas ${ }^{17}$, e muitas vezes é obscuro e errático. Essa relação suscita uma das perguntas básicas que motiva os estudiosos da escrita: "Em qual nível da estrutura linguística [da fala] são as unidades do sistema de escrita interpretadas e como essas unidades refletem características estruturais das línguas para as quais eles proveem uma forma escrita" (Coulmas, 2003, p.34)? Os representacionistas irão argumentar a favor da abstração de uma escrita cujo fluxo é basicamente unidimensional e que portanto reflete o fluxo unidimensional temporal da fala. Essa é uma clara simplificação que exclui completamente qualquer relevância do jogo bidimensional da escrita, seja em sistemas que fazem uso claro desta bidimensionalidade - com diacríticos e outros sinais - até outros usos que evidenciam mais abertamente a sua

16 Além da análise de Auroux (1979, 2004, [1992]2009) sobre a historicidade da metalinguagem e das categorias linguísticas, também nos apoiamos em Orlandi (2001) e em sua proposta de uma linguística "contra as abstrações mutilantes."

17 As motivações de ortografias aparentemente assistemáticas foram objeto de intensas discussões na história das ideias linguísticas, em particular nos projetos de reforma ortográfica na França em Inglaterra nos séculos XVII e XVIII. Para uma discussão extensa sobre esses projetos, veja Hudson (1994) 
bidimensionalidade - como no caso de tabelas e esquemas, na poesia concreta, etc. (Auroux, 2004, capítulo 2)

Finalmente, concedemos que a escrita é historiável e historiada, uma vez que ela tem um caráter permanente em meio físico e visível, direcionado para leitores que muito raramente estão presentes no ato da escrita, ao passo que a fala é efêmera e temporal. ${ }^{18}$ Sua dimensão histórica é analisável e carrega um material muito rico, suporte para a linguística diacrônica. Nesta evolução temporal, a escrita e as outras dimensões da linguagem interagem de forma complexa. A escrita parece intervir na maneira como as línguas evoluem, em geral uma âncora conservadora que resiste à mudança linguística, em contraste com a maior "flexibilidade" da fala, cujo caráter fugidio também se reflete na riqueza e velocidade com que novas formas surgem e desaparecem. O porquê deste suposto caráter relativamente conservador da escrita também é uma questão que frequenta os discursos sobre a relação entre fala e escrita. A visão tradicional representacionista costuma não dar grande relevância ao impacto da permanência da escrita sobre a língua falada ou mesmo questionar as razões desse descompasso temporal entre escrita e fala.

Em suma, a herança representacionista/foneticista propõe a domesticação das diferenças entre os dois sistemas linguísticos e insiste na atribuição de um papel secundário à escrita. Podemos elencar neste cenário pelo menos quatro importantes características aviltantes para a escrita:

1) O advento da língua escrita na história tem pouca repercussão cognitiva / ontológica / de visão de mundo; ${ }^{19}$

2) O verdadeiro advento da escrita, a passagem da "protoescrita" para uma escrita "totalmente desenvolvida" está condicionado à representação

18 Através de instrumentos de gravação sonora no século XIX também a fala tornou-se historiável uma vez que seus registros podem ser guardados e acessados em qualquer momento no tempo. Este paralelo, todavia, não considera pelo menos dois aspectos contrastantes entre os registros da escrita e da fala: 1) a escrita é tradicionalmente utilizada como acesso aos registros da língua e da história, ao passo que o uso da fala registrada é ainda restrito a uma parcela mínima de pesquisadores com interesses específicos; 2) a fala, ainda que registrável, mantém seu aspecto fugidio e temporário uma vez que aquele que ouve seus registros tem acesso sempre em um espaço de tempo limitado, ao passo que o aspecto gráfico da escrita a mantém permanente e imediatamente acessível sobre a mídia onde está inscrita.

19 Obviamente não estamos falando do aspecto técnico-ferramental. Não há quem ponha em dúvida os profundos impactos da escrita na civilização humana. Para uma discussão das diferentes dimensões do impacto da escrita na civilização humana, veja-se, por exemplo, Rubin (1995, epílogo). 
(mínima que seja) da fala nas unidades gráficas da escrita;

3) A tipologia de cada sistema de escrita é ontologicamente inócua, ou seja, apenas alguns sistemas de escrita são mais ou menos "eficientes" do que outros no seu papel de representação da fala;

4) De forma geral, a escrita é secundária em relação à fala, um sistema semiológico baseado sobre o sistema semiológico da fala (a escrita se apresenta como um metassigno da fala). A fala tem portanto prioridade estrutural, funcional e ontológica sobre a escrita.

A despeito do papel pouco enobrecedor outorgado à escrita sob as lentes foneticistas, vimos que as questões levantadas acima nos dão a entrever a precariedade do edifício representacional e, consequentemente, nos obrigam a revisar as características aviltantes elencadas acima. De uma forma ou outra, um ou mais destas quatro características serão colocadas à prova pelos autores que veremos na próxima seção.

\section{Três propostas alternativas}

Vimos acima que a proposição de uma estrutura isomórfica entre fala e escrita, ponto de partida para um teoria da representação da fala na escrita (foneticismo), suscita uma série de problemas e questionamentos. Ademais, como já comentado, as próprias categorias linguísticas utilizadas nas esferas da fala e da escrita dependem da própria forma como consideramos sua articulação. Há portanto uma gama de problemas relacionados a esta relação "imperfeita," que frequentemente tentam ser pacificados na justificativa de "falhas" estruturais derivadas da inevitável mudança do meio sonoro para o meio gráfico. Os estudos "tradicionais" sobre a escrita parecem tratar o assunto como apenas uma questão de complexidade, suficientemente suavizada (embora nunca eliminada) pelo progressivo refinamento do mapeamento das unidades fonéticas representadas na escrita. Todavia o presente artigo sugere que nos perguntemos sobre as premissas iniciais sobre as quais repousa a possibilidade da representação fonética na escrita.

A ideia citada acima de que as protoescritas são um tipo de "subescrita" é subvertida por aqueles que, embora ainda partidários do representacionalismo, entendem que a escrita que abre mão da fala como suporte representativo - na chamada por alguns de escrita ideográfica ou pictográfica - deve ser considerada um sistema apto com todas as potencialidades esperadas de seu meio. 
Como vimos, esta é a chamada visão semanticista da escrita. ${ }^{20}$ Este partido teórico é particularmente relevante - e polêmico - aos estudos daquela que é o único sistema de escrita disseminada atualmente em uso com um inegável importe semântico, a escrita chinesa. ${ }^{21}$ Podemos considerar que o semanticismo atinge o último elo da cadeia representacionalista aristotélica sem que penetre o seu cerne.

Há todavia linhas de estudo e visões do mundo que se preocupam menos com o "percentual de foneticidade" nas diversas escritas do mundo e se propõem a questionar diretamente não só a posição da escrita ao final da cadeia aristotélica, mas a própria cadeia como um todo. Nada mais natural, quando negado o paradigma representacionista, que a heteronomia da escrita, subserviente à fala, também seja colocada em questão. Veremos que há diferentes formas e metodologias de articular esse questionamento.

\subsection{Ernest Fenollosa e o caractere chinês como meio para a poesia}

Ernest Fenollosa (1853-1908) foi um entusiasmado orientalista que morou mais de dez anos no Japão, onde estudou e lecionou na Universidade Imperial de Tóquio. A despeito de não ser um especialista em chinês clássico, seus cadernos de anotações sobre a poesia clássica chinesa foram uma peça fundamental na constituição do aclamado trabalho do poeta americano Ezra Pound publicado em 1915 no inovador livreto intitulado Cathay. ${ }^{22}$ Fenollosa escreveu também um influente ensaio não terminado intitulado "The Chinese Written Character as a Medium for Poetry," publicado postumamente em 1919, e a base para a discussão nesta seção. ${ }^{23}$ Seu trabalho foi recebido com fartos elogios por alguns estudiosos da teoria literária ( "one of the high points of modern poetics",

20 Alguns autores contemporâneos que exploraram o potencial de figuratividade da escrita sem o suporte direto da fala são: Vachek (1973), Haas (1976), Faber (1992), Boone \& Mignolo (1994), Schmandt-Besserat (1997) e Houston (2004).

21 Para uma discussão detalhada sobre o debate foneticista/semanticista sobre a questão da escrita chinesa, veja-se Autor (2011). A disputa pela "natureza" da escrita chinesa reflete-se também nos trabalhos de Creel (1936), Hansen (1993), Boltz (1994), Alleton (1997, 2008), Bottéro et al (2006) e Lurie (2006).

22 “[...] Cathay [...], publicado em 1915 compete com The Wast Land (1922) de Elliot e Harmonium (1923) de Stevens pelo título da mais influente coleção poética na língua inglesa do século XX" (Saussy et al, 2008, p.3).

23 As citações do ensaio de Fenollosa usadas no presente artigo foram tiradas de Campos (1977). Para a versão completa do artigo original em inglês acompanhada de detalhada análise, veja-se Saussy et al (2008). Para uma discussão minuciosa do Cathay de Pound, veja-se Wai-lim (1969). 
Andrew Welsh, Roots of Lyric, 1978, citado em Percy, 2009) ao mesmo tempo em que foi execrado pela maioria dos sinólogos ("a small mass of confusion ... tilting at the unoffending windmills" (Kennedy, 1958, p.2).

Foi através da poesia que Fenollosa teve um contato mais íntimo com o chinês clássico e com sua escrita: "um dos alvos primeiros do ensaio de Fenollosa é a tradução de poesia, entendida como operação re-criadora" (Campos, 1977, p.31). As raízes da atividade poética encontram-se na íntima relação entre significante e significado e a tese do orientalista americano sugere que elas se fixariam melhor no fértil solo da escrita chamada por ele de "ideográfica." Assim tal método "pictorial" seria a melhor forma de se mostrar e criar poesia. Sua visão sempre foi carregada de um elemento afetivo pela língua chinesa, que poderia ser (e muitas veze é) criticado e rotulado como ingênuo. Entretanto, o trabalho de Fenollosa ofereceu possibilidades antes inauditas a partir de sua abordagem tão particular da escrita chinesa. Ao mesmo tempo que reconheceu os limites do seu conhecimento técnico e concedeu que o chinês por ele idealizado não corresponderia exatamente ao seu uso corrente, para Fenollosa seu objeto de estudo é a linguagem escrita poética ideal e isso acabou por libertá-lo de uma série de constrangimentos que limitaram outros pensadores sobre o assunto.

Como iríamos descrever a escrita chinesa na concepção fenollosiana? Poderíamos procurar resumir em algumas características fundamentais apresentadas em seu estudo, que envolvem não somente a escrita, mas também a língua falada chinesa. Entre as principais e mais relevantes para o presente trabalho, destacam-se quatro:

1) os signos chineses não são meros símbolos arbitrários, são motivados graficamente. "[Os caracteres] têm vida" (Fenollosa, [1912]1977, p.123), a notação chinesa "baseia-se numa pintura vívida e sucinta das operações da natureza" (Fenollosa, [1912]1977, p.122);

2) tais significantes evocam mais do que sons comunicativos, e sim uma mistura de música e movimento, portanto se adéquam perfeitamente à poesia;

3) as palavras chinesas originam-se no verbo e "grande número [das] raízes ideográficas carregam consigo uma ideia verbal de ação" (Fenollosa, [1912]1977, p.124);

4) as categorias gramaticais se confundem na língua chinesa, uma mesma palavra (e caractere) pode ter a função de substantivo, verbo, adjetivo, 
advérbio, etc. ${ }^{24}$

A análise de Fenollosa chama a atenção para o papel da língua e da escrita chinesa na sua "lógica de correlação" e nos esquemas paradigmático-paralelísticos (Campos, 1977, p.70) que "parece[m] coincidir com a tendência da própria linguagem poética oriental a romper com [os paradigmas abstrato-imaginativo-analógicos] da lógica ocidental." (Campos, 1977, p.70; Liu, 1962) O que está sendo proposto pelo orientalista não é uma análise crítica do que pode ou não ser explicado pela etimologia e pela linguística chinesa, mas as possibilidades que se abrem quando vemos na escrita a expressão de uma ordem que não se oferece na fala. Ainda mais do que expressão, uma evocação inatingível pela fala. A escrita chinesa, assim vista, tem um poder ilocucionário e pragmático que vai além da fala.

Desta forma o texto de Fenollosa abre espaço para instigantes teses sobre a escrita, destacadas a seguir:

1) Os caracteres apontam para sua própria diacronia, contam a sua história. As possibilidades ideográficas são abertamente oferecidas no chinês, ao passo que a escrita alfabética favorece mais o fluxo unidimensional do som, evidenciando "a anemia de um discurso moderno" (Fenollosa, [1912]1977, p.140);

2) as imagens gráficas dos caracteres não devem ser vistas no sentido de uma representabilidade pictórica fidedigna, mas em um sentido metafórico-poético. Não importa se suas etimologias estejam estritamente corretas ou não, mas as possibilidades que se abrem, do jogo visual, das alusões que se projetam além da fala;

3) o chinês é fiel à natureza quando age como um segundo edifício metafórico construído sobre o edifício metafórico da linguagem. A própria Natureza é metafórica em si mesma, ela "grita" que é uma metáfora ("eu tenho uma história!"), não é uma ordem dócil que se oferece passivamente à experiência e que se dá a ver ao pensamento abstrato. É neste sentido que a escrita chinesa seria mais "natural,"

4) o ideograma dá a ver a ação, observando as coisas tecerem seus próprios destinos, ao passo que uma fotografia solidificaria e congelaria. Seria uma interpretação ingênua pensar que os caracteres seriam meros portadores

24 Estas são características geralmente associadas ao conhecimento "pré-científico" da língua falada e escrita chinesa e já no tempo de Fenollosa eram colocadas em questão pelo crescente número de sinólogos trabalhando na China. Para maiores detalhes, veja-se Autor (2011). 
de um significado estável e "fixo" "por trás." O que está em ação é um jogo de significantes no seu "uso poético;"

5) a notação chinesa favorece mais o verbo do que o nome e inverteria o paradigma representacionista, onde até o verbos são nomes de ações. O chinês evidenciaria que: "um nome verdadeiro, uma coisa isolada, não existe na Natureza. As coisas são apenas pontos terminais, ou melhor, pontos de encontro de ações." (Fenollosa, [1912]1977, p.124)

6) a escrita chinesa ilumina a razão pela qual a sentença é uma forma universal: "nenhuma sentença integral completa de fato um pensamento" (Fenollosa, [1912]1977, p.125) e a frase não captura nada e não se completa: é o fulgor de um relâmpago vocacionado a se extinguir. Ver uma frase como simples formadora de uma relação de união entre sujeito e predicado seria recair na subjetividade, retirar a sentença da Natureza, seu verdadeiro lugar onde as sentenças nutrem seu poder evocativo e sua convicção.

Sem dúvida Fenollosa construiu uma visão peculiar e extremamente enobrecedora da escrita chinesa, e, em particular, da escrita chinesa. Ao mesmo tempo em que seu texto é literário e extremamente poético, o trabalho do autor certamente carrega pretensões filosóficas em suas implicações metafísicas: "A forma da sentença foi imposta aos homens primitivos pela própria Natureza [...] ela é reflexo da ordem temporal da causalidade." (Fenollosa, [1912]1977, p.127) Seu texto é frequentemente marcado por tentativas em ver a língua chinesa (e sua escrita) em uma posição privilegiada de proximidade em relação a esta ordem, como por exemplo, quando observa que: "se o chinês ignora a gramática, isso se dá pelo fato de que 'a Natureza, ela própria, não ter gramática'." (Campos, 1977, p.68)

É relativamente fácil criticar o trabalho de Fenollosa mostrando algumas inverdades científicas sobre o que ele afirmou da escrita chinesa. ${ }^{25}$ Assim seu ensaio foi alvo fácil daqueles que viram em seu trabalho alucinações poéticas

25 Por exemplo: a) os caracteres que ele examina em seu artigo parecem casos típicos de um "nutrir o espírito com um só exemplo," (Wittgenstein, 2009, §593) e são mais exceções do que regra em chinês; b) alternativamente, os registros arqueológicos mostram que alguns caracteres não foram etimologicamente formados da maneira que supôs o autor; c) a sintaxe chinesa (clássica) está longe de ser uma simples “ordem natural de causa e efeito," que poderia se supor pela pobreza morfológica da língua; d) existem palavras no chinês clássico que são verbos típicos ou outras que são substantivos típicos; e) seria uma simplificação excessiva chamar a escrita chinesa de "uma simples escrita figurativa." 
travestidas de uma análise científica rigorosa (se é que Fenollosa jamais tivesse tal pretensão).

Entretanto, seguindo a linha abrangente da epistemologia de Auroux (2004), não devemos descartar as ideias de Fenollosa pelo simples fato de que não podemos nos fechar dentro de qualquer uma verdade absoluta. Mais especificamente, não devemos ignorar o efeito que seu texto teve nas representações ocidentais da escrita chinesa. Como nos ensina Aurouz, não há critério único e definitivo de valor que hierarquize tais representações e que nos obrigue a invalidar o que escreveu o orientalista. Seguindo o que escreve Orlandi (2001), necessitamos lutar contra as "abstrações mutilantes" que excluem os espaços onde julga-se que "não se produz ciência" e sim, ao contário, nos abrir para melhor "compreender o processo de construção e os sentidos dessas instituições [linguísticas] e dos sujeitos sócio-históricos que as habitam/praticam" (p. 9).

O trabalho de Fenollosa é ambicioso, poético, confuso e instigante, que nos oferece um modo alternativo de apreciar o semanticismo na escrita, e mais especificamente, suas possibilidades no âmbito da escrita chinesa.

\subsection{Sylvain Auroux e a revolução tecnológica da gramatização}

A história das línguas foi sempre marcada pelas pressões socioculturais dos povos da Terra, e intimamente ligada às noções de cultura e identidade nacional. A partir do advento histórico da escrita, a consolidação do saber sobre uma língua através de dicionários e gramáticas tornou-se um dos símbolos maiores da sobrevivência de cada língua e cultura associada. Mais do que um símbolo, o influente linguista e filósofo francês Sylvain Auroux nos propõe que a escrita de uma língua a constitui enquanto tal, dando-lhe sua existência, possibilitando que desenvolvamos uma reflexão sobre essa língua e sobre a linguagem, somente possível através dessa mesma escrita.

Em seu livro A Revolução Tecnológica da Gramatização Auroux explora esta via ao privilegiar a escrita não apenas como um artefato tecnológico (o que ela obviamente é), mas também como uma entidade fundadora e criadora da linguagem, da qual ela seria indissociável. Seu advento histórico não deveria ser, e nem poderiam ser considerado, psicológica, ontológica ou funcionalmente inócuo. ${ }^{26}$

Auroux nos propõe duas teses mestras sobre a escrita e seu aparecimento:

26 Outros autores que subscrevem em grande parte o partido teórico de Auroux sobre a escrita e apresentam uma pesquisa original sobre o assunto são Olson (1994) e Taylor (1997). 
1) a escrita proporcionou uma verdadeira revolução tecnológica, que possibilitou as primeiras reflexões sistemáticas sobre a linguagem e o aparecimento da metalinguagem e; 2) a constituição dos dicionários e gramáticas das línguas, processo por ele nomeado "gramatização," desenhou (e continua a desenhar) um mapa da comunicação e das línguas no mundo, e concedeu ao Ocidente uma posição ímpar de controle e conhecimento sobre as culturas da Terra. ${ }^{27}$ Embora as duas posturas tenham implicações fundamentais para a escrita e a linguagem, neste artigo nos interessa primariamente sua primeira tese, uma vez que ela coloca em questão a tese da heteronomia da escrita em relação à fala.

Para o autor francês não há verdadeiro saber gramatical oral. Ele admite nas sociedades ágrafas a existência de uma reflexão sobre a linguagem, e usa como exemplo a comunidade dos Dogon e sua complexa visão sobre linguagem e a palavra (Auroux, 1992, p.20). Todavia Auroux argumenta que nesse caso não há um processo de abstração, da retirada do simbólico do real, uma vez que para os Dogon as palavras são coisas, não são suas representações. Dessa forma não haveria a necessidade da escrita reificar a palavra, uma vez que ela já é considerada concreta e o real é inteiramente simbólico. Assim como os Dogon, outras civilizações desprovidas de escrita também não seriam capazes de dar o passo fundamental da metalinguagem, da verdadeira reflexão linguística.

Estão em jogo aqui dois tipos de saberes sobre a linguagem: em primeiro lugar, o saber epilinguistico é aquele tipo do qual todo o locutor possui sobre sua língua e sobre a natureza da linguagem. Ele não é reflexivo, mas quase que intuitivo e inconsciente (não-representado), ${ }^{28}$ o que parece ser o que ocorre com os Dogon. Por outro lado, o saber metalinguístico é constituído e manipulado através de uma metalinguagem.

Se por um lado aprendemos a falar uma nova língua simplesmente falando, não parece correto dizer que aprendemos uma escrita simples e automaticamente escrevendo. Há um outro aprendizado em jogo: “contrariamente à competência linguística [da fala], é um sistema já completamente formado que é transmitido. É sem dúvida isso que redobra o papel da escrita no desenvolvimento dos saberes linguísticos" (Auroux [1992]2009, p.28).

27 Para um estudo minucioso do papel da gramatização na línguas do ocidente, veja também, em particular, Auroux (1995b).

28 O conceito de saber epilinguístico é bastante complexo e seria simplista equacioná-lo a uma simples intuição sobre a língua. Auroux argumenta que tal saber, mesmo que não representado fisicamente, pode ser manipulado "sob a forma de relações conscientes com o seu objeto" (Auroux, [1992]2009, p.17). Assim sendo, a relação entre o epilinguístico e o metalinguístico seria melhor compreendida como um continuum em que ambos se interpõem e entrelaçam-se. 
Todavia não seria correto, diz Auroux, considerar que seja a escrita a origem do saber linguístico. Não temos aqui uma origem, mas sim um processo ao qual a escrita estaria inexoravelmente inscrita. $\mathrm{O}$ autor não está propondo a reversão da hierarquia fala/escrita e sua história da linguagem pretende ser não-teleológica, com a adoção de uma atitude descritiva, não colocada sob uma perspectiva de evolução. ${ }^{29}$ Auroux não diz que não há a possibilidade do saber nas sociedades ágrafas, mas sim que a escrita é um sistema a partir do qual o processo de abstração se torna possível. É importante todavia destacar que esta abstração não foi, para o autor, o fator que causou o aparecimento da escrita, que não surge vocacionada para o saber metalinguístico, mas sim antes de mais nada para suporte mnemônico oral, para a literatura. A tese central de Auroux sustenta que "a escrita é antes de tudo um saber técnico construído sobre um saber epilinguístico inconsciente" (Auroux, 2004, p.70).

Auroux nos chama a atenção para o aspecto concreto da escrita como crucial: "o processo de aparecimento da escrita é um processo de objetivação da linguagem [...], ele precisa do aparecimento de técnicas autônomas e inteiramente artificiais [...]" (Auroux, [1992]2009, p.21, meu grifo). Como seria, argumenta o autor, o empreendimento de um estudo sistemático, usando tabelas, listas e hierarquias, em um contexto exclusivamente oral? E como escapar do momento unidimensional, que sempre é fugidio e característico do fluxo da fala, sem a adoção de técnicas de escrita que permitam uma visão simultânea de fenômenos que normalmente assim não se apresentam?

Auroux está especialmente interessado nos momentos de limiar da escrita. ${ }^{30}$ Em qualquer cultura (ágrafa ou não) há elementos da "passagem" do epi- para o metalinguístico, de especulações sobre a origem da linguagem. Mas "não encontramos em nenhuma civilização oral um corpo de doutrina elaborado em relação às artes da linguagem, mesmo onde podemos observar que certos indivíduos são especializados no papel de tradutores ou "poetas"" (Auroux, [1992]2009, p.21, p.19).

A escrita, para o autor francês, primeiro produz textos, e não parece imediata e espontaneamente produzir reflexões sobre a natureza da linguagem.

29 Auroux subscreve em seu trabalho a posição de neutralidade epistemológica: "não faz parte de nosso papel dizer se isto é mais ciência do que aquilo [...] ciência pode ser uma palavra normativa de nossa linguagem-objeto, mas em nossa metalinguagem será apenas uma palavra descritiva" (Auroux, [1992]2009, p.14).

30 Na seção anterior, onde os discursos foneticistas foram apresentados, esse momento de "passagem" para uma escrita "completa" também foi um objeto de intenso escrutínio, embora tomado de uma forma totalmente diversa àquela que Auroux nos propõe aqui. 
"Mas o que faz deslanchar verdadeiramente a reflexão linguística é a alteridade, considerada essencialmente do ponto de vista da escrita" (Auroux, [1992]2009, p.21, p.24). O aparecimento e desenvolvimento do saber linguístico surge quando a escrita fixa a linguagem e a coloca como um objeto a ser resolvido diante do sujeito. As primeiras marcas desta resolução aparecem sob a forma de estudos filológicos e lexicográficos.

Em contraste, não foram os momentos de comunicação derivados das necessidades de trocas comerciais que provocaram qualquer especulação além de meras generalidades sobre a diversidade linguística. Pois, segundo Auroux, não foi da necessidade de falar uma língua outra qualquer que nasceu a primeira análise gramatical, mas antes da vontade de se compreender um texto.

Dicionários e gramáticas, neste contexto, não foram apenas manuais descritivos de uma ou outra língua, criados unicamente para satisfazer uma necessidade didática, mas sim instrumentos linguísticos, produtos de interesses práticos e sociais, submersos em um contexto ideológico-cultural, instrumentos para regular uma língua literária. Tudo isso seria impossível sem a escrita.

Ao mesmo tempo em que Auroux delega à escrita um lugar privilegiado na evolução dos fatos linguísticos e a inscreve no núcleo do nosso conhecimento sobre a linguagem, em certas passagens de sua obra ele parece que resvala na tese representacionista da escrita: a escrita "não é toda manifestação gráfica, mas somente aquela que aparece a partir do momento em que a representação gráfica tem por objetivo a representação da linguagem. É o que viu Aristóteles na sua célebre definição [...]" (Auroux, 2004, p.73). Entretanto ao complexificar a natureza da transposição entre os meios da fala e da escrita, como vimos, Auroux descarta a visão trivial da representação de uma por outra. O autor francês em particular nos chama a atenção para a grande importância do aspecto bidimensional (gráfico) da escrita, que a torna muito mais do que mera adaptação da fala em meio físico. Desta forma, na opinião de Auroux, embora seja possível falar de escrita como representação, não é uma transposição isomórfica inócua. Nos parece então que o autor francês dialoga com as análises "foneticistas" acima no momento em que entende a escrita em seu aspecto dual fonético e semântico, baseado no seu cuidadoso estudo diacrônico das línguas naturais e de seus sistemas de escrita. Podemos interpretar que Auroux parece querer trazer o argumento da sua razão gráfica como substituto da razão pictográfica, em contraste ao estudo de Fenollosa, apresentado na seção anterior. Nos dois autores, entretanto, o gráfico e o pictográfico, cada um à sua maneira, concedem à escrita um impacto não somente sobre nossas práticas linguísticas, mas sobre a própria fala e nosso conceito de linguagem. 


\subsection{Roy Harris e repensando a escrita}

Roy Harris (1931-2015), professor da Universidade de Oxford e eminente linguista, propôs uma forma bastante inovadora de se pensar a linguagem e as línguas. Seu extenso trabalho é brevemente introduzido aqui com o objetivo de mostrar de que forma para Harris a escrita toma um papel protagonista nos estudos da linguagem. $\mathrm{O}$ autor inicia seu pensamento sobre o assunto no livro The Origin of Writing de 1986, desenvolvido em Signs of Writing de 1995 até Rethinking Writing de 2001. A despeito de sua importância na linguística mundial, os livros de Harris até hoje ainda não foram traduzidos para o português.

$\mathrm{Na}$ linha de autores como Sylvain Auroux e David Olson, Harris entende que a escrita é crucial para compreendermos a cognição humana e a reflexão sobre a língua de um povo. Neste sentido, estaríamos equivocados em pensá-la como um simples substituto ou representação da fala, ou seja, apenas "servindo para tornar os sons "visíveis"” (Harris, 2001, p.xii).

$\mathrm{O}$ argumento de Harris envolve uma crítica profunda e minuciosa da revolução semiológica encabeçada por Saussure para explicar a linguagem. A reformulação do autor inglês implica numa nova forma de pensar não somente a escrita, mas também toda a ciência da linguagem. É o que Roy Harris batizou de Linguística Integracional, da qual nos concentraremos aqui apenas nos aspectos em que envolve a escrita.

É certamente um lugar-comum dizer que a introdução da escrita revolucionou a forma de pensar das sociedades e daqueles povos que passaram a adotá-la. A escrita implicou na "criação de um status social para seus iniciados e a aceitação de uma escala de valores [...] e isso em geral requereu, entre outras coisas, uma revisão das ideias sobre a linguagem" (Harris, 2001, p.6). Segundo Harris, alguns pensadores, como Marshall McLuhan (1964), Eric Havelock (1986) e W.J. Ong (1992) equacionaram escrita com civilização e levaram seus potenciais às últimas consequências, vendo a escrita não como "simples" tecnologia, mas como algo muito mais poderoso: "a escrita, pensou-se, 'reestrutura a consciência. ${ }^{31}$ A reivindicação é que quando o homo scribens eventualmente sucedeu o homo loquens um novo tipo de mentalidade apareceu pela primeira vez na história da raça humana" (Harris, 2001, p.13). Embora Harris reconheça os grandes méritos desta nova aceitação do papel cognitivo e cultural da escrita, para o autor falta a estes estudos uma análise crítica que

31 Harris não considera válida a hipótese de que a escrita "re-estruture" a cognição e o pensamento. Veja Harris, 2001, p.228-237. Para uma discussão sobre a relação da escrita e cognição, além dos autores citados por Harris, veja-se Rubin (1997, epílogo), Goody (1987), entre outros. 
justifique plenamente estas potencialidades, que surge pela proposta de uma nova semiologia da escrita, objetiva e independente. Sua finalidade é quebrar com a tradição que avalia a escrita em termos da sua capacidade e precisão na transcrição da fala.

Harris toma a visão saussuriana da linguística como um ramo da semiologia como ponto de partida para suas propostas. Os signos saussurianos, segundo Harris, possuem necessariamente um significado público reconhecido, uma base social (Harris, 2001, p.47). Mais ainda, formam um sistema que funciona com base nas relações e diferenças entre os signos linguísticos. Aqui vemos os paralelos no sistema de signos da escrita: 1) signos (grafemas e suas pronúncias) arbitrários socialmente definidos; 2) valores dos grafemas definidos por diferença e negatividade e obtidos dentro de um sistema fixo com número determinado de grafemas (a inserção ou exclusão de um grafema afeta o sistema como um todo) e; 3) tipologia e aspecto físico da escrita são ambos irrelevantes. Harris partirá deste tripé para repensar a natureza dos sistemas de escrita.

O autor inglês avalia como insuficiente a análise semiológica de Saussure sobre as relações entre os signos escritos. Para Harris, no sistema saussuriano a identificação do par sinal gráfico ( grafema) X significante sonoro abstrato implicaria a codeterminação simultânea de significante e significado. ${ }^{32}$ Para Harris é difícil entretanto aceitar esta premissa e ao mesmo tempo não se sentir compelido a comparar as formas alográficas de um grafema qualquer, com uma lista finita anteriormente existente de letras (um repertório de grafemas), o que nos tornaria obrigados a considerar um grafema prototípico, usado como base para o julgamento de suas formas alográficas.

Identificar as variantes alográficas com base nas suas ligações comuns com um repertório finito de sons básicos (os fonemas), seria também errado, pois implicaria em dar um valor positivo para os grafemas (por exemplo, os alógrafos de "t" seriam assim identificados por possuírem uma pronúncia igual, equivalente a algum fonema / $\mathrm{t} /$ abstrato). E como lidar com o fato de que apesar das variações gráficas serem aceitas em diferentes línguas (no caso do exemplo com "t", escritas alfabéticas), a ligação entre o grafema " $t$ " e seu

32 Quando Harris se refere neste estudo sobre Saussure a um "sistema de escrita" ele parece restringir-se às escritas ditas cenêmicas, ou seja, semanticamente "vazias". Daí o pareamente significante/significado que reflete-se no binário grafema/expressão sonora. A exploração do contraste oferecido pelas escritas semanticamente relevantes (escritas chamadas de plerêmicas) aparece, no presente artigo, mais claramente nas especulações de Fenollosa sobre a escrita chinesa. Todavia, veremos adiante que esta separação acaba sendo complexificada no pensamento de Harris. 
correspondente fonema varia de língua para língua? Mais ainda, já que cada língua tem um inventário diferenciado de grafemas, cada sistema deve se definir de maneira também diferente, e apesar disso, as formas alográficas de " $t$ " (no exemplo que estamos tomando) valem para todas estas línguas que utilizam o grafema. Harris ainda levanta o questionamento sobre como considerar algumas formas específicas para os grafemas - como maiúsculas (vs. minúsculas), itálicos, negrito, etc. - todas referidas pelo mesmo nome (" $t$ ", no exemplo, para t, para T, para $\mathbf{t}$ ou para $t$ ), e sobre as quais todavia se podem conceber diferentes funções semiológicas. Na análise do autor,

Ao insistir que a escrita seja um sistema separado semiologicamente daquele da fala e que, ao mesmo tempo, os sinais escritos sejam meramente metassinais [metasigns] para significar os sinais da fala, ele [Saussure] cria um dilema para si mesmo. (Harris, 2001, p.63)

Roy Harris então propõe sua Semiologia Integracional, na qual os signos não são propriedade de alguma sociedade que os tenha criado, mas sim formados através daquela que é essencialmente uma habilidade caracteristicamente humana, dentro de uma atividade e necessariamente ligados a um determinado contexto. $\mathrm{O}$ mesmo seria válido para o signo escrito e para a relação entre os dois sistemas semióticos, fala e escrita.

Para elucidar a interpenetração dos dois sistemas, Harris utiliza o exemplo da redução da vogal não tônica em inglês e dos sons virtualmente indistinguíveis entre "postman" e seu plural "postmen." Não faz sentido falar em duas gramáticas distintas (uma para a fala e outra para a escrita), mas da maneira como fala e escrita são usados em contextos integracionais diferentes. Ao ditar a forma singular, o falante pode optar por "artificialmente" enfatizar o vogal variante, e deste jeito estará modificando a forma oral para satisfazer uma necessidade comunicativa derivada da escrita. A escrita estaria "desambiguando" a fala neste aspecto, o que reverte radicalmente a tradicional primazia desta sobre aquela. Enfim, escrita e fala seriam "formas integradas de comunicação, e não apenas paralelas, mas formas separadas de comunicação que simplesmente se apresentam disponíveis" (Harris, 2001, p.75), formas estas que interagem de uma maneira que Harris chama de simbiótica. Ou seja, do mesmo modo como a pronúncia das palavras afeta sua escrita, a maneira como as palavras são escritas acaba por afetar o jeito como são pronunciadas. A interação ocorre sempre contextualizada, dentro das situações comunicacionais, não pode ser pensada, diz Harris, como uma ordem dada e fixada por convenção social. 
Não haveria assim nada de "eterno" ou "duradouro" na escrita, este erro seria devido à confusão entre o que é o documento físico (escrito) e o que é são os signos escritos.

A partir do momento em que a escrita é vista como um sistema semiológico distinto da fala e composto por signos escritos, torna-se necessária a "distinção entre uma notação (notation) e uma escrita (script)" (Harris, 2001, p.91). A notação é o repertório de grafemas, que só adquirem algum valor como signos escritos dentro dos textos de um sistema de escrita. Harris usa o exemplo simples dos grafemas "c", "h", "a", "i" e "r". Mesmo apresentados juntos e grafados como "chair," eles, enquanto puramente elementos de uma notação, não têm qualquer valor. Uma vez dentro do sistema da escrita inglesa tomam a acepção de "cadeira," ao passo que no sistema da escrita francesa, sua acepção é de "carne." Este é o nível mais básico da escrita que faltaria à análise de Saussure. Harris usa uma metáfora esclarecedora: os grafemas (notação) são como peças de um quebra-cabeça e a escrita (script) é o quebra-cabeça montado. Saussure veria apenas sentido se o quebra-cabeça montado mostrasse alguma figura surgida na comunhão de suas peças (a imagem que mostra um quebra-cabeça), e assim deixaria de perceber o nível mais fundamental da notação. Nessa metáfora há duas estruturas semióticas envolvidas: aquelas das peças e a do quebra-cabeça montado. Note que isso não significa separar letras de palavras. O "quebra-cabeça montado" deve ser visto como a abstração de um sistema de escrita, não como um conjunto de letras. ${ }^{33}$

Outra forma de visualizar a diferença notação/escrita se espelha na distinção entre maiúsculas e minúsculas. Notacionalmente se trata da mesma letra (por exemplo, falamos apenas na letra "a", e não nos "a" minúsculo" e "a" maiúsculo), mas dentro do sistema de escrita, as formas maiúsculas e minúsculas assumem funções e usos diferenciados. A capitalização das letras seria portanto, uma característica não da notação, mas dos sistemas de escrita (script) e tem diferentes interpretações segundo cada uma das escritas que a utilizar. ${ }^{34}$

Que não haja relação fixa entre os grafemas e suas pronúncias aparece claramente pela própria possibilidade de se transferir letras (grafemas) de um sistema de escrita para outro. Se os grafemas não compusessem uma notação (notation), não seria possível emprestá-los para outras escritas sem que junto

33 Harris exemplifica mostrando um sistema semiológico em que essa distinção fica mais evidente. Na matemática há uma clara separação entre o que são cifras, ou algarismos, e o que é são números. Os algarismos compõe a base notacional da matemática, retendo sua identidade notacional independente do número que eles compõem.

34 Veja por exemplo a diferença do uso das maiúsculas entre o alemão e o português. 
se carregasse sua pronúncia. Destacando a identidade da notação, Harris aponta para a substancialidade da escrita vis-à-vis aquela da fala. Há um "certo grau de organização independente" (Harris, 2001, p.98) em suas unidades, o que obviamente não ocorre na efêmera fala. Podemos historiar a notação da escrita, pensar na sua evolução social, nas similaridades e padrões que se impõem à evolução diacrônica dos grafemas, não tomados como "explicação" para o funcionamento de um sistema de escrita, mas que se apresenta de forma muito mais concreta do que as abstratas evoluções diacrônicas dos padrões fonológicos: "letras e algarismos são artefatos culturais. Sons não o são." (Harris, 2001, p.99) Não há, neste estado de coisas, como aceitar que as letras e a escrita sejam meros representantes da fala.

Harris também aborda a questão do valor linguístico saussuriano (na escrita) de uma forma diferenciada. $\mathrm{O}$ autor argumenta que a insistência de Saussure sobre o valor puramente diferencial das entidades do sistema é "uma das originalidades e forças do pensamento de Saussure. Mas é ao mesmo tempo o calcanhar de Aquiles da semiologia saussuriana," (Harris, 2001, p.106) porque a escrita é uma das instâncias em que o valor é baseado em algo diferente de uma pura rede de diferenças. Em contraste Harris propõe que se considere a possibilidade de um valor positivo para o signo gráfico.

Harris identifica as seguintes características estruturais do sistema notacional da escrita: 1) cada membro tem uma forma específica (e suas aloformas/ alógrafos) que o diferencia dos demais; 2) há uma hierarquização de prioridades no sistema e 3) o número de membros do sistema é fixo. Tais sistemas o autor inglês chama de emblematic frames, da qual a notação da escrita seria um exemplo (Harris, 2001, p.106-109). A hierarquização de prioridades é uma propriedade do sistema que não é auferida por diferenças. A classificação alfabética só é concebível se houver um valor hierárquico atribuído a cada membro da notação da escrita. ${ }^{35}$ Há portanto uma estruturação desse sistema que não depende somente da relação das diferenças entre seus membros.

A partir do momento em que postulamos uma notação para a escrita, é inevitável perguntar se as letras, ${ }^{36}$ como unidades notacionais, correspondem aos fonemas como unidades fonológicas. Harris argumenta que sim, mas também que não. O fonema é uma unidade teórica, e, "como tal, baseada nas letras.

35 Tão importante é a noção de hierarquização nos sistemas de escrita, que mesmo para as escrita não alfabéticas, como é o caso da escrita chinesa, foram desenvolvidos critérios de hierarquização.

36 Harris faz sempre referências às "letras" ao invés do termo mais genérico "grafemas." 
Por mais sofisticado que seja o sistema fonológico, sua segmentação básica é invariavelmente representada na transcrição através de letras alfabéticas de algum tipo." (Harris, 2001, p.118) Os fonemas não existem a priori, mas são sim o produto de uma análise fonológica, já as letras são concretas, unidades gráficas visíveis, que carregam uma história e que precisam ser aprendidas. Nenhuma criança ou adulto aprende a falar estudando um inventário de fonemas. Ao contrário das letras, é teoricamente incoerente conceber que um mesmo fonema ocorra em duas línguas diferentes.

Conquanto a análise de Harris parece claramente voltada para os sistemas de escrita cenêmicos, ${ }^{37}$ para o autor todos os sistemas de escrita são mistos, pois envolvem signos fonéticos e "ideogramas" (como, por exemplo, os números, sinais como $\$, \&$ e outros). O jogo entre os dois tipos diferentes de signos já pode ser vislumbrado no argumento sobre a imobilidade da escrita no próprio Saussure. Escreveu o linguista suíço que "o signo escrito tende naturalmente a se tornar um ideograma. Esta é a consequência inevitável do uso social da escrita e portanto da familiaridade com as formas escritas" (Harris, 2001, p.149). O leitor não precisa soletrar todas as palavras que lê, a leitura é quase automática, ela não "passa pela fala" ou pela dissecação fonológica. Assim todos os sistemas de escrita são inevitavelmente mistos, um embate entre o estabelecimento da análise ortográfica do significante vocal e a tendência oposta na direção de uma ideografia.

Olhando como um todo a complexa argumentação de Roy Harris, observamos como o autor não se prende àquela obsessão que domina quase todos os discursos sobre a relação entre escrita e fala, nomeadamente, se a escrita pode ou não ser usada e compreendida sem que se recorra à fala. Harris se adianta a este problema, pois acredita que qualquer sistema de escrita, mesmo aquele mais abertamente fonético, não pode ser tomado com uma representação da fala. Ao comentar brevemente a posição de alguns autores (DeFrancis, Sampson, Coulmas, Cohen e Diringer) sobre o assunto, Harris pontua que as controvérsias existentes carecem de "qualquer critério semiológico bem fundado" (Harris, 2001, p.156). A independência semiológica da escrita não dependeria, em sua visão, da ortografia utilizada, mas da própria natureza da articulação da escrita enquanto um sistema semiótico independente.

$37 \quad$ Veja-se nota 32 


\section{Conclusão: Porque a escrita é pertinente para a linguística?}

Os estudos que discutem a escrita tomando uma abordagem cultural, comunicacional ou funcional, frequentemente reconhecem o imenso impacto social, cultural, cognitivo e pedagógico desta nova tecnologia. ${ }^{38} \mathrm{O}$ presente artigo teve o objetivo de trazer o tema da escrita para o bojo dos estudos da linguagem, onde, ela frequentemente assume um papel coadjuvante e permanece pouco explorada em sua complexidade e importância.

Reconhecendo a ousadia ao propor uma colagem de autores que sequer focam-se sobre o mesmo tema, insistimos aqui que tal provocação é parte de um movimento capaz de deslocar não apenas ideologias prontamente aparentes, mas, de uma forma mais sutil, convicções pré-conceituais profundamente arraigadas, que incluem, mais especificamente, uma escrita que seja mero suporte representacional para a fala, da qual, em última instância, é completamente dependente.

Os três autores aqui selecionados tomam abordagens inteiramente diferentes ao lidarem com suas questões, que nem mesmo são todas especificamente relacionadas à escrita enquanto um sistema linguístico: o foco de Fenollosa é a poesia chinesa, a preocupação de Auroux é com o conhecimento metalinguístico e só em Harris o sistema da escrita aparece explicitamente protagonista de seu texto. Do ponto de vista de uma teoria sobre a escrita, Fenollosa é um autor que claramente não discute ou questiona o paradigma representacionalista na linguagem ou na escrita. Todavia, ao aceitar a possibilidade de uma representação figurativa e diferenciada no chinês poético, o autor abre espaço para uma visão semanticista da escrita e propõe seu distanciamento da fala. Sylvain Auroux, por outro lado, ainda que também não ofereça explicitamente um questionamento à visão representacionalista da escrita, propõe trazê-la ao centro e origem da articulação metalinguística, o que nitidamente outorga à escrita um poder muito além daquele como mera representação inerte da fala. Finalmente, Harris parece ser o autor que aqui vai mais longe, propondo uma semiologia independente do sistema da escrita. $\mathrm{O}$ autor inglês articula o que muitos estudiosos sobre a escrita sugerem mas não desenvolvem: "a escrita é uma nova linguagem" (Higounet, 1955[2004], p.10).

A proposta do presente artigo é de suscitar questões e chamar atenção para uma certa precariedade na posição simplista que afirma que

38 Repete-se aqui algumas referências, como por exemplo: Havelock (1986), Goody (1987), Martin ([1988]1994), Vicent Lucci (In: Catach, 1996, cap.10) e Rubin (1997). 
A escrita não é particularmente linguagem, mas meramente uma forma de gravar a linguagem [...]; o uso da escrita [...] acaba por se mostrar, quando analisado, um mero derivativo da linguagem. (Bloomfield, 1933[1955] in Householder, 1971, p.248)

Como vimos, os três autores introduzidos neste artigo tem interesses, abordagens, contextos históricos de produção, objetos de pesquisa e conclusões muito diversos entre si. Entretanto um fio condutor une seus estudos: o uso da escrita e do sistemas de escrita ultrapassa aquele de um simples desejo de representação da fala em um meio permanente e estável. Mais ainda, sua utilização acarreta efeitos consideráveis sobre a linguagem falada, a forma como praticamos a linguística e até como concebemos a própria linguagem.

\section{Referências}

ALLETON, Viviane (org). Paroles à dire, parole à écrire. Paris: Édition de l'école des hautes études en sciences sociales, 1997.

. L'écriture chinoise: le défi de la modernité. Éditions Albin Michel: Paris, 2008.

ARISTÓTELES. De Interpretatione. In: Ontologia e Predicação em Aristóteles, Lucas Angioni (introdução, tradução e comentário), coleção Textos Didáticos no 41, Campinas: Instituto de Filosofia e Ciências Humanas, Unicamp, 2000. AUROUX, Sylvain. Catégories des Metalangages. Histoire Épistémologie Langage, tome 1, fascicule 1, 1979.

. A Revolução Tecnológica da Gramatização. Trad.Eni Puccinelli Orlandi. Campinas: Ed. Unicamp, [1992]2009.

. Histoire des Idées Linguistiques (tome 1). Pierre Mardaga Editeur: Liège, 1995.

Liège, $1995 \mathrm{~b}$.

. Histoire des Idées Linguistiques (tome 3). Pierre Mardaga Editeur: Liège, 2000.

. La Philosophie du langage. Paris: Ed. Presses Universitaires de France, 2004.

BAKER, G.P. \& HACKER P.M. Wittgenstein: understanding and meaning: part I-Essays. Wiley-Blackwell - $2^{\text {nd }}$ ed., 2009

BOLTZ, William. Origin and Early Development of the Chinese Writing System. New Haven, American Oriental Series, vol 78, 1994. 
BOONE, Elizabeth, MIGNOLO, Walter. Writing Without Words: Alternative Literacies in Mesoamerica and the Andes. Duke University Press, 1994.

BOTTÉRO, Françoise and DJAMOURI, Redouane. Écriture chinoise: données, usages et répresentations. EHESS, Paris, 2006.

CAMPOS, Haroldo (org.). Ideograma: Lógica Poesia Linguagem. São Paulo: Ed. Cultrix, 1977.

CATACH, Nina (org) Para uma teoria da língua escrita. São Paulo, Editora Ática, 1996.

CLODD, Edward. The Story of the Alphabet. London: George Newnes Ltd, 1900.

COHEN, Marcel. La Grande Invention de l'écriture et son évolution. In: Histoire et Art de l'Écriture. Paris: Ed. Robert Laffont, [1958]2005.

COMRIE, Bernard. The World's Major Languages. Oxford University Press, 1990.

COULMAS, Florian. Writing Systems: an introduction to their linguistic analysis. Cambridge University Press, 2003.

.(ed.) The Blackwell Encyclopedia of Writing Systems. Oxford: Blackwell Publishing, 1996.

. Evaluating merit - the evolution of writing reconsidered. wsr. oxfordjournals.org, 2009. Acessado em 11/08/10.

CREEL Howard. On the Nature of Chinese Ideography. T'oung Pao Second Series, Vol. 32, Livr. 2/3, pp. 85-161, 1936.

DeFRANCIS, John. Visible Speech: the diverse oneness of writing systems. Honolulu: University of Hawai'i Press, 1996.

DANIELS, Peter. Fundamentals of Grammatology, Journal of the American Oriental Society 110: 727-731, 1990.

DANIELS, Peter, BRIGHT, William (org). The World's writing systems. Oxford: Oxford University Press, 1996.

DERRIDA, Jacques. Gramatologia, p.3-32, 132-146. Trad. Miriam Chnaiderman e Renato Janine Ribeiro. Editora Perspectiva, [1967]2004. . Posições, Belo Horizonte: Autêntica, 2001.

DIRINGER, David . A Escrita. Rio de Janeiro: Editorial Verbo, [1962]1985. . The Alphabet: A key to the history of mankind. (v. $1 \& 2$ ) (3rd Edition). New York: Funk \& Wagnalls, 1968.

EDGERTON, William F. On the theory of writing. In Journal of Near Eastern Studies, 11:287-90, 1952.

FABER, Alice. Phonemic segmentation as epiphenomenon: evidence from the history of alphabetic writing. In: DOWNING Pamela, LIMA Susan D, 
NOONAN Michael (ed). The Linguistics of Literacy. Amsterdam: John Benjamins Publishing Co, 1992.

FENOLLOSA, Ernest. Os caracteres da escrita chinesa como instrumento para a poesia. Trad. Heloysa de Lima Dantas. In: CAMPOS, Haroldo (org.) Ideograma: Lógica Poesia Linguagem. São Paulo: Ed. Cultrix, [1912]1977. FISCHER, Steven R. História da Escrita. São Paulo: Editora Unesp, 2009. GALVÃO, Ana Maria de Oliveira e BATISTA, Antônio Augusto Gomes. Oralidade e Escrita: Uma Revisão. Cadernos de Pessquisa ,v.36, n.128, pp 403-432, maio/ago. 2006.

GOODY, Jack. The Interface between the Written and the Oral. Cambridge University Press, 1987.

GELB, I.J. A study of writing. University of Chicago Press, 1963.

GNANADESIKAN, Amalia. The Writing Revolution: cuneiform to the internet. Wiley-Blackwell, 2009.

GROSSWILER, Paul. Dispelling the Alphabet Effect. Canadian Journal of Communication, v. 29, n. 2, 2004.

HAAS, William (ed). Writing without letters. Manchester University Press, 1976.

. Writing: the basic option. p.131-208, 1975. In: PULGRAM, Ernst. The typologies of writing systems. p.1-29, 1966.

HANSEN, Chad. Chinese Ideographs and Western Ideas. The Journal of Asian Studies, Vol. 52, No. 2, pp. 373-399, 1993.

HARRIS, Roy. The Language Myth. London: Duckworth, 1981. . The Origin of Writing, Open Court Pub Co, 1986.

. Language, Saussure and Wittgenstein: How to play games with words. London: Routledge, 1988.

. Re-thinking Writing. London: The Athlone Press, 2001.

HARRIS, Roy \& TAYLOR, Talbot. Landmarks in Linguistic Thought, volume 1. London and New York: Routledge, 1997.

HAVELOCK, Eric. The Muse Learns to Write: Reflections on Orality and Literacy from Antiquity to the Present. New Haven: Yale University Press, 1986 HIGOUNET, Charles. História Concisa da Escrita. Ed. Parábola, [1955]2004 HILL, Archibald. The Typology of Writing Systems. IN: AUSTIN, William M. (ed) (1967). Papers in Linguistics: in honor of Léon Dostert pp 92-99. The Hague: Mouton, 1967.

HOUSEHOLDER, Fred. Linguistic Speculations. Cambridge at the University Press, 1971. 
HOUSTON, Stephen, (org). The first writing: script invention as History and Process. Cambridge University Press, 2004.

HUDSON, Nicholas Writing and European Thougth - 1600-1830. Cambridge University Press, 1994.

JAKOBSON, Roman. Lingüística e comunicação. São Paulo: Ed. Cultrix, [1954]2005.

JOSEPH, John \& LOVE, Nigel Talbot. Landmarks in Linguistic Thought, volume 2. London and New York: Routledge, 2001.

KAVANAGH, James F. (ed). Language by Ear and by Eye: The Relationship between Speech and Reading. Cambridge: MIT Press, 1974.

KENNEDY, George. Fenollosa, Pound and the Chinese Characters, Yale Literary Magazine vol. 126:5, p.24-36, 1958.

LEPSCHY, Giulio. (ed) History of Linguistics vol 2: Classical and Medieval Linguistics. Routledge, 2014.

LEPSCHY, Giulio. (ed) History of Linguistics vol 3: Renaissance and Early Modern Linguistics. Routledge, 2014b.

LIU, James J. Y. The Art of Chinese Poetry. Chicago: University of Chicago Press, 1962.

LURIE, David. Language, writing, and disciplinarity in the Critique of the "Ideographic Myth": Some proleptical remarks. Language \& Communication 26 250-268, 2006.

LYONS, John: Linguagem e Linguística (uma introdução). Trad. Marilda Winkler Averburg \& Clarisse Sieckenius de Souza. Rio de Janeiro: TLC Editora, 1987.

MARTIN, Henri-Jean. The History and Power of Writing. Chicago University Press, [1988]1994.

MARTINET, André. Elementos de Linguística Geral. Lisboa: Livraria Sá da Costa Editora, 1960.

MORPURGO DAVIES, Anna (ed) History of Linguistics vol 4: Nineteenth-Century Linguistics. Routledge, 2014.

McLUHAN, Marshall. Understanding media. New York: Mentor, 1964.

MUSSALIM, Fernanda e BENTES, Anna Christina. Introdução à linguística. v.3: fundamentos epistemológicos. São Paulo: Cortez Editora, 2004.

OLSON, David R. The World on Paper: the conceptual and cognitive implications of writing and reading. Cambridge University Press, 1994

ONG, Walter. Orality and literacy: The technologizing of the word. London: Methuen, 1982. 
ORLANDI, Eni (Org). História das Ideias Linguísticas: Construção do Saber Metalinguístico e Constituição da Língua Nacional. Unemar Editora Pontes, 2001.

PAULUK, Marcel. Sistemas de escrita: abordagens, tipologias, perspectivas em semiótica. Dissertação (Mestrado em Comunicação e Semiótica). Pontifícia Universidade Católica de São Paulo, 2003.

PERCY, Carol. Ezra Pound and the Chinese Written Language, 2009. http:// www.chass.utoronto.ca/ cpercy/courses/6362Pickard2.htm, acesso em 11/05/2010.

POMMIER, Gérard. Naissance et renaissance de l'écriture. Presses Universitaires de France: Paris, 1993.

POWELL, Barry. Writing: Theory and History of the Technology of Civilization. Wiley-Blackwell, 2009.

ROGERS, Henry. Writing Systems: A Linguistic Approach. Malden: Blackwell Publishing, 2005.

RUBIN, David. Memory in Oral Traditions: The Cognitive Psychology of Epic, Ballads, and Counting-out Rhymes. Oxford University Press, 1997

SAMPSON, Geoffrey. Sistemas de escrita: tipologia, história e psicologia. São Paulo: Ática, [1985]1996

SAPIR, Edward. Language: An Introduction to the Study of Speech. London: Granada Publishing Limited, [1921]1963.

SAUSSURE, Ferdinand de. Curso de Linguística Geral. Trad. Antônio Chelini, José Paulo Pires e Izidoro Blikstein. São Paulo: Ed. Cultrix, [1916]2006.

SAUSSY, Haun; STALLING, Jonathan e KLEIN, Lucas (orgs.) The Chinese Written Character as a Medium for Poetry: a critical edition written by Ernest Fenollosa and Ezra Pound. New York: Fordham University Press, 2008.

SCHMANDT-BESSERAT, Denise. How Writing Came About. University of Texas Press; Abridged edition, 1997.

TANNEN, Deborah (ed.). Spoken and Written Language: Exploring Orality and Literacy. Norwood: Ablex Publishing Co, 1982.

TAYLOR, Talbot. Theorizing Language. Emerald Press, 1997.

VACHEK, Josef. Written language: General problems and problems of English (Janua linguarum. Series critica) The Hague: Mouton, 1973.

WAI-LIM Yip. Ezra Pound's Cathay. Princeton University Press, 1969.

WITTGENSTEIN, Ludwig. Philosophische Untersuchung - Philosophical Investigations transl. ANSCOMBE, G.E.M, HACKER, P.M.S and SCHULTE, Joachin. Wiley-Blackwell, 2009. 
WOODS, Christopher (ed.) with TEETER, Emily \& EMBERLING, George (2010). Visible Language: inventions of writing in the ancient middle east and below. The Oriental Institute, 2010.

Recebido em 27 de junho de 2016.

Aceito em 29 de setembro de 2016. 